\title{
Penggunaan model Pembelajaran Time Token Untuk Meningkatkan Hasil Belajar Pada Mata Pelajaran IPA Kelas IV SDN 3 Manonjaya
}

\author{
Universitas Perjuangan Tasikmalaya \\ rina.rahnawati@gmail.com
}

Rina Rahnawati, Ade Maftuh, Winarti Dwi Febriani

\section{Article History}

accepted 2/11/2019

approved 23/11/2019

published 31/12/2019

\begin{abstract}
This study aims to describe the use of the time token learning model to improve student learning outcomes in science subjects $4^{\text {th }}$ grade SDN 3 Manonjaya located in Manonjaya District. The research method used was the classroom action research (CAR) method which consists of three cycles. Based on observation activities obtained data on student learning outcomes preaction with the value of student learning completeness $37.5 \%$ and an average of $67.9 \%$. Data collection techniques used are qualitative data and quantitative data. Qualitative data through observation and documentation. While quantitative data by giving questions about student learning outcomes are given at the end of each cycle. The results showed an increase in student learning outcomes in the first cycle, second cycle, and third cycle that is by getting $56.25 \%$ in the first cycle with enough categories, second cycle $75 \%$ good category, third cycle $87 \%$ very good category. Whereas in student activities, cycle I gained $96.4 \%$ in the adequate category, cycle II $80.5 \%$ in the good category, and cycle III $94.4 \%$ in the very good category. The conclusion of this research is the time token learning model can improve learning outcomes and activities of fourth grade students of SD Negeri 3 Manonjaya.
\end{abstract}

Keywords: Learning Outcomes, Learning Models, Time Token, Science Learning, Elementary School.

\begin{abstract}
Abstrak
Penelitian ini bertujuan untuk mengetahui penggunaan model pembelajaran time token untuk meningkatkan hasil belajar siswa pada mata pelajaran IPA kelas IV SD Negeri 3 Manonjaya yang terletak di Kecamatan Manonjaya. Metode penelitian yang digunakan yaitu metode penelitian tindakan kelas (PTK) yang terdiri dari tiga siklus. Berdasarkan kegiatan observasi diperoleh data hasil belajar siswa pra tindakan dengan nilai ketuntasan belajar siswa 37,5\% dan rata-rata $67,9 \%$. Teknik pengumpulan data yang digunakan yaitu dengan data kualitatif dan data kuantitatif. Data kualitatif melalui observasi dan dokumentasi. Sedangkan data kuantitatif dengan pemberian soal tes hasil belajar siswa yang diberikan setiap akhir siklus. Hasil penelitian menunjukan peningkatan hasil belajar siswa pada siklus I, siklus II, dan siklus III yaitu dengan memperoleh $56,25 \%$ pada siklus I dengan ketegori cukup, siklus II $75 \%$ kategori baik, siklus III 87\% kategori sangat baik. Sedangkan pada aktivitas siswa, siklus I memperoleh $96,4 \%$ dengan kategori cukup, siklus II 80,5\% ktegori baik, dan siklus III 94,4\% ktegori sangat baik. Kesimpula dari penelitian ini adalah model pembelajaran time token dapat meningkatkan hasil belajar dan aktivitas siswa kelas IV SD Negeri 3 Manonjaya.
\end{abstract}

Kata kunci: Hasil Belajar, Model Pembelajaran, Time Token, Pembelajaran IPA, Sekolah Dasar.

Social, Humanities, and Education Studies (SHEs): Conference Series https://jurnal.uns.ac.id/shes

p-ISSN 2620-9284

e-ISSN 2620-9292 


\section{PENDAHULUAN}

Penyelenggaraan pendidikan merupakan salah satu kegiatan yang memfokuskan pada proses belajar mengajar dengan melibatkan guru sebagai pendidik dan siswa sebagai peserta didik pada suatu jenjang pendidikan untuk mengembangkan kemampuan dirinya dan meningkatkan kualitas pendidikkan menjadi lebih baik, sehingga dapat meningkatkan hasil belajar siswa.

Pelajaran IPA merupakan salah satu pelajaran yang berkaitan dengan lingkungan alam dimana semua kebutuan hidup yang diperlukan manusia berasal dari alam. Siswa di sekolah sangat penting untuk mempelajari pelajaran IPA karena berkaitan dengan kehidupan sehari-hari. Menurut Nugraha (2017:2) "pembelajaran IPA di SD merupakan tempat untuk membekali siswa dengan pengetahuan, keterampilan, dan sikap yang diperlukan untuk menyesuaikan diri dengan perubahan-perubahan di sekelilingnya". Terdapat tujuan pembelajaran IPA di SD menurut Sulistiyorini dalam Nugraha (2017:13) ialah "ikut serta dalam memelihara, menjaga dan melestarikan lingkungan alam, menghargai berbagai macam bentuk ciptaan Tuhan di alam semesta ini untuk dipelajari". Pembelajaran IPA diharapkan dapat menjadi tempat bagi siswa untuk mempelajari diri sendiri dan alam sekitar, serta prospek pengembangan lebih lanjut dalam menerapkannya di dalam kehidupan sehari-hari (Widiana, 2016:150).

Berdasarkan hasil observasi di SDN 3 Manonjaya, nilai Kriteria Ketuntasan Minimal (KKM) siswa adalah 68. Dari 16 orang siswa yang telah mencapai KKM 6 siswa atau 37,5\%, sedangkan 10 siswa atau 62,5\% belum mencapai KKM. Nilai ulangan IPA siswa sebagian besar belum dapat mencapai kriteria yang diharapkan, diperlukan perbaikan supaya nilai hasil belajar siswa dapat mencapai KKM. Menurut Abdurrahman bahwa hasil belajar merupakan kemampuan yang diperoleh anak setelah melalui kegiatan belajar (Marti, dkk. 2014:23). Menurut Afandi, dkk., 2013:4) hasil belajar akan tampak pada beberapa aspek antar lain: pengetahuan, pengertian, kebiasaan, keterampilan, apresiasi, emosional, hubungan sosial, jasmani, etis atau budi pekerti, dan sikap.

Pelajaran IPA salah satu mata pelajaran yang berkaitan dengan lingkungan alam sangat penting untuk dipelajari oleh siswa. Siswa setelah melakukan kegiatan pembelajaran dapat lebih mengenal alam, yang nantinya siswa dapat menjaga, melestarikan alam untuk kehidupan generasi selanjutnya. Oleh sebab itu diperlukan alternatif solusi yang dalam pembelajaran berpusat pada siswa dengan menggunakan model pembelajaran time token. Model pembelajaran Time Token adalah suatu model pengajaran guru dengan menggunakan pembelajaran secara kooperatif yang tekniknya dapat membantu siswa dalam kegiatan belajar, dimana siswa bekerja sama dengan kelompok, dan memberikan kupon bicara sesuai dengan materi yang dibahas atau dipresentasikan (Rahman, dkk. 2017: 24).

Terdapat hasil penelitian yang telah dilakukan oleh Bawembang (2018:8), Windi, dkk. (2018:328), Ningzaswati, dkk. (2015:11) bahwa,

"aktivitas belajar siswa dengan penggunaan model pembelajaran kooperatif tipe time token lebih baik dari pada aktivitas belajar siswa yang mengikuti model pembelajaran konvensional dalam meningkatkan hasil belajar siswa, pemahaman konsep pembelajaran dan kemampuan berbicara siswa".

Tujuan penelitian yaitu mendeskripsikan perencanaan penggunaan model pembelajaran time token untuk meningkatkan hasil belajar pada mata pelajaran IPA kelas IV. Mendeskripsikan mengenai pelaksanaan penggunaan model pembelajaran time token untuk meningkatkan hasil belajar pada mata pelajaran IPA kelas IV dan mendeskripsikan peningkatan hasil belajar pada mata pelajaran IPA kelas IV dengan penggunaan model pembelajaran time token. 


\section{METODE}

Metode penelitian ini menggunakan metode penelitian tindakan kelas (PTK). Penlitian dilakukan di SDN 3 Manonjaya kelas IV pada mata pelajaran IPA dengan menggunakan model pembelajaran time token. Data yang digunakan pada penelitian ini yaitu data kualitatif yang diperoleh melalui observasi, dan dokumentasi berupa datadata siswa dan gambar-gambar selama proses pembelajaran.

Sedangkan data kuantitatif diperoleh dari hasil pemberian soal-soal tes di setiap siklus.Teknik pengambilan sampel dengan non probability sampling menggunakan sampling jenuh. Jumlah sampel pada penelitian ialah 16 orang siswa yang terdiri dari 9 siswa laki-laki, 7 siswa perempuan. Teknik pengumpulan data menggunakan observasi, dokumentasi, dan tes hasil belajar. Analisis data melalui reduksi data, display data, kesimpulan dan verifikasi.

\section{HASIL DAN PEMBAHASAN}

Kompetensi dasar (KD) yang digunakan pada penelitian ini yaitu 3.7 Mengidentifikasi hubungan sumber daya alam dengan lingkungan, teknologi, dan masyarakat. Materi yang diajarkan macam-macam sumber daya alam yang dapat diperbaharui, dan tidak dapat diperbaharui, hasil sumber daya alam dengan pemanfaatan teknologi, dampak pengambilan sumber daya alam secara berlebihan, dan upaya menjaga sumber daya alam dalam kehidupan sehari-hari. Pelaksanaan penelitian dilakukan dengan tiga siklus. Hasil penelitian setiap siklus terdapat perencanaan, pelaksanaan, observasi, dan refleksi. Sedangkan pada pembahasan terdapat perencanaan, pelaksanaan, dan peningkatan hasil belajar yang dapat dilihat sebagai berikut.

Perencanaan pembelajaran yang dilakukan dengan membuat rencana pelaksanaan pembelajaran (RPP) disesuaikan dengan model pembelajaran time token. Menyusun soal tes yang akan diberikan pada siswa dalam lembar kerja siswa (LKS) dan lembar soal evaluasi siswa. Membuat instrumen pengumpulan data berupa lembar observasi siswa dan alat penilaian kinerja guru (APKG). Pelaksanaan penelitian dilakukan sesuai RPP yang telah dibuat. Untuk memperoleh data saat penelitian berlangsung dibuat pedoman observasi siswa yang penilaiannya diberikan oleh guru mitra. Pedoman observasi disesuaikan dengan langkah-langkah model pembelajaran time token. Sedangkan untuk mengetahui hasil belajar siswa diberikan soal evaluasi di setiap akhir siklus. Kegiatan penelitian yang telah dilakukan di peroleh hasil belajar siswa dan aktivitas belajar siswa dari siklus I, siklus II, dan siklus III dengan menggunakan model pembelajaran time token yang dapat dilihat pada tabel 1 . di bawah ini.

Tabel 1. Perbedaan Peningkatan Hasil Belajar Siswa dan Aktivitas Belajar Siswa

\begin{tabular}{lllll}
\hline \multirow{2}{*}{ Siklus } & \multicolumn{2}{c}{ Hasil Belajar Siswa } & \multicolumn{2}{l}{$\begin{array}{l}\text { Aktivitas Belajar Siswa } \\
\text { menggunakan Model } \\
\text { Pembelajaran Time Token }\end{array}$} \\
& Skor & Kriteria & Skor & Kriteria \\
\hline I & $56,25 \%$ & Cukup & $69,4 \%$ & Cukup \\
II & $75 \%$ & Baik & $80,5 \%$ & Baik \\
III & $87,5 \%$ & Sangat Baik & $94,4 \%$ & Sangat Baik \\
\hline
\end{tabular}

Berdasar pada tabel 1. terdapat peningkatan hasil belajar siswa dan aktivitas belajar siswa yang dilakukan dari siklus I, siklus II, dan siklus III yaitu dengan memperoleh 56,25\% pada siklus I dengan ketegori cukup, siklus II 75\% kategori baik, siklus III 87\% kategori sangat baik. Sedangkan pada aktivitas siswa, siklus I memperoleh $96,4 \%$ dengan kategori cukup, siklus II 80,5\% ktegori baik, dan siklus III $94,4 \%$ ktegori sangat baik. 
Penelitian dilakukan tiga siklus menggunakan model pembeljaran time token. Terdapat perencanaan pembelajaran, pelaksanaan pembelajran, dan penigkatan hasil belajar sebagai berikut. Perencanaan pembelajaran yang dilakukan dari siklus I, Siklus II, dan Siklus III dengan membuat rencana pelaksanaan pembelajaran (RPP) disesuaikan dengan model pembelajaran time token yang diajarkan di kelas IV pada mata pelajaran IPA. Mempersiapkan materi pada mata pelajaran IPA tentang sumber daya alam yang akan diajarkan. Mempersiapakan media pembelajaran berupa gambar-gambar tentang sumber daya alam, dan kupon berbicara. Menyusun soal tes yang akan diberikan pada siswa dalam lembar kerja siswa (LKS) dan lembar soal evaluasi siswa. Membuat instrumen pengumpulan data berupa lembar observasi siswa dan alat penilaian kinerja guru (APKG), pada pelaksanaan pembelajaran yang sesuai dengan penggunaan model pembelajaran time token.

Pelaksanaan pembelajaraan diawali dengan berdoa, menyanyikan lagu nasional, memberikan pertanyaan untuk mengungkapkan pengetahuan awal siswa, dan menyampaikan tujuan pembelajaran. Pembelajaran dilakukan dengan tiga siklus untuk meningkatkan hasil belajar siswa pada mata pelajaran IPA menggunakan model pembelajaran time token. hasil belajar siswa diperoleh setelah mengikuti kegiatan belajar dengan mengerjakan soal evaluasi. Hal tersebut sesuai dengan pendapat Abdurrahman dalam (Marti, dkk. 2014:23) bahwa hasil belajar merupakan kemampuan yang diperoleh anak setelah melalui kegiatan belajar.

Data peningkatan hasil belajar siswa, dan aktivitas belajar siswa, pada penelitian ini yang dapat dilihat pada diagaram berikut ini.

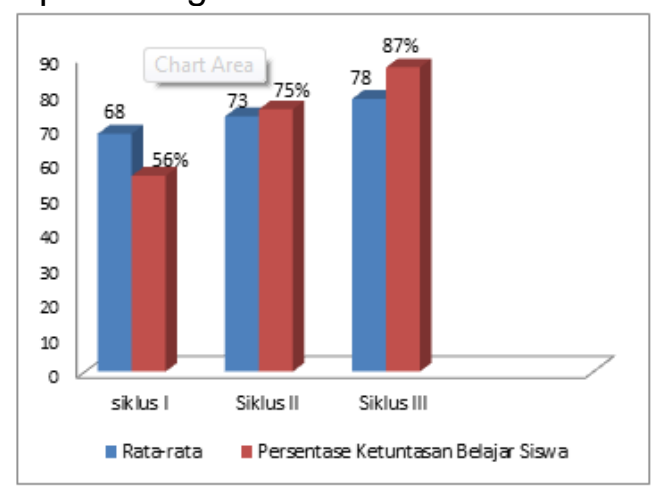

Gambar 1. Diagram Peningkatan Hasil Belajar Siswa

Berdasar pada gambar 1. diagram peningkatan hasil belajar siswa kelas IV SD Negeri 3 Manonjaya menujukan siklus I rata-rata belajar siswa $(68,5 \%)$ lebih tinggi dibandingkan dengan persentase ketuntasan belajar siswa $(56,25)$ dikarenakan masih banyak siswa yang belum mencapai KKM. Siklus II perbandingan rata-rata belajar siswa $(73 \%)$ dengan persentase ketuntasan belajar siswa $(75 \%)$ tidak jauh berbeda, karena jumlah nilai siswa lebih sedikit dari pada jumlah hasil belajar siswa yang tuntas. Siklus III sama dengan siklus II yaitu rata-rata hasil belajar siswa lebih kecil dibandingkan dengan persentase ketuntasan belajar siswa. Siklus III memperoleh ratarata $78 \%$ dan persentase ketuntasan belajar siswa $87 \%$. 


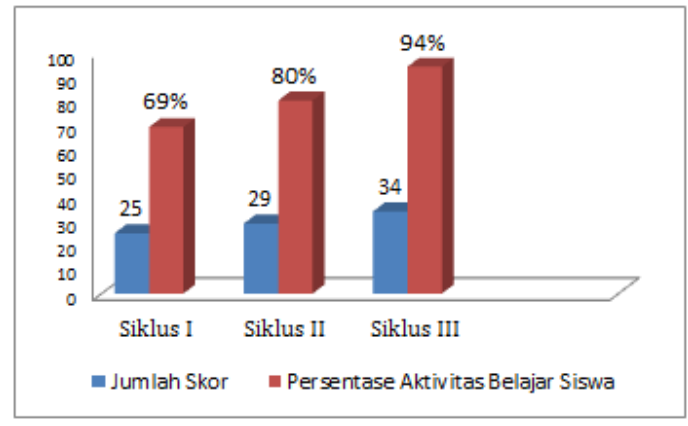

Gambar 2. Diagram Peningkatan Aktivitas Belajar Siswa

Berdasar pada gambar 2. diagram peningkatan aktivitas belajar siswa kelas IV SD Negeri 3 Manonjaya pada siklus I 69,4\%, siklus II 80,5\%, siklus III 94,4\%. Data tersebut menunjukkan peningkatan dari aktivitas siklus I, siklus II, dan siklus III. Berdasarkan hasil penelitian, dapat disimpulkan bahwa terdapat peningkatan hasil belajar siswa dengan menggunakan menggunakan model pembelajaran time token pada mata pelajaran IPA kelas IV SD Negeri 3 Manonjaya.

\section{SIMPULAN}

1. Perencanaan pembelajaran time token dilakukan dengan membuat RPP, media pembelajaran, dan materi pelajaran yang disesuaikan dengan langkah-langkah pada model pebelajaran time token.

2. Pelaksanaan penggunaan model pembelajaran time token untuk meningkatkan hasil belajar siswa sebagian besar telah sesuai dengan perencanaan pembelajaran, walaupun terdapat beberapa kendala dari siklus I, siklus II, dan siklus III.

3. Pembelajaran time token pada mata pelajaran IPA, materi sumber daya dengan tiga siklus dapat meningkatkan hasil belajar siswa. Terbukti dengan adanya peningkatan hasil belajar siswa pada siklus I nilai rata-rata hasil belajar siswa 68,5, jumlah siswa yang tuntas atau mencapai KKM 56,25\%. Siklus II nilai rata-rata 73,1, jumlah siswa tuntas $75 \%$. Siklus III nilai rata-rata 78 , jumlah siswa yang tuntas belajar $87,5 \%$.

\section{DAFTAR PUSTAKA}

Afandi, M. Chamalah, dan E. Wardani, O.P. (2013). Model dan Metode Pembelajaran di Sekolah. Semarang: UNISSULA PRESS.

Bawembang. (2018). Kemampuan Berbicara Melalui Model Pembelajaran Time Token Siswa Kelas VII a SMP Negeri 4 Tondano Tahun Ajaran 2017/2018. Jurnal IImiah Bahasa dan Seni, 5 (2).

Ningzaswati, dkk. 2015. Pengaruh Model Pembelajaran Kooperatif Teknik Time Token Terhadap Aktivitas Belajar dan Hasil Belajar IPA Siswa Kelas VI. Jurnal Pendidikan Dasar Indonesia, 5 (1).

Nugraha. A. (2017). Pendidikan IPA Kelas Tinggi. Tasikmalaya: UPI PRESS.

Marti, dkk. (2014). Efektivitas Pembelajaran Kooperatif Tipe NHT (Numbered Heads Together) Dengan Media Visual Terhadap Hasil Belajar Siswa Pada Materi Organisasi Kehidupan Di Kelas VII SMP Rehoboth. Jurnal Pendidikan Matematika dan IPA. 5 (2)

Rahman, dkk. (2017). Penerapan Model Pembelajaran Time Token Dalam Meningkatkan Hasil Belajar Bahasa Indonesia Siswa SDN 200 Lompu Kecamatan Cina Kabupaten Bone. Jurnal IImiah IImu Kependidikan, 1 (1).

Widiana, I. (2016). Pengembangan Asesmen Proyek Dalam Pembelajaran IPA Di Sekolah Dasar. Jurnal Pendidikan Indonesia. 5 (2). 